\title{
Invasive rodents on islands: integrating historical and contemporary ecology
}

\author{
Donald R. Drake · Terry L. Hunt
}

Received: 16 June 2008/Accepted: 24 September 2008/Published online: 9 December 2008

(C) Springer Science+Business Media B.V. 2008

The colonization of islands by humans dramatically transformed environments, initiating extinctions, extirpations, and a complex array of ecosystem changes (e.g. Kirch 1997; Grayson 2001; Anderson 2008; Athens et al. 2002; McConkey and Drake 2002; Steadman 2006; Kennett et al. 2006). Researchers in historical ecology have described these human-induced transformations as consequences of forest clearing, fire, and the introduction and establishment of a portmanteau biota (Crosby 2004). Rodents (especially the rats Rattus exulans, $R$. rattus, and $R$. norvegicus) may have been the most widely introduced vertebrates to accompany humans in our history of global dispersal. Indeed, one could argue that rats (Rattus spp.) are the original invasive "species"-from the colonization of the Pacific Islands to the global expansion of Europeans. Ecological, palaeoecological, and archaeological studies have documented the direct and indirect impacts of rodents on native plants and animals, and implicated them in transforming many island environments (e.g. Atkinson 1985; Diamond 1985; Athens et al. 2002; Steadman 2006; Towns et al. 2006; Hunt 2007; Jones

D. R. Drake ( $\square)$

Botany Department, University of Hawaii, Honolulu, HI 96822, USA

e-mail: dondrake@hawaii.edu

T. L. Hunt

Anthropology Department, University of Hawaii, Honolulu, HI 96822, USA et al. 2008). However, in some cases, effects attributed to rodents are based on circumstantial evidence, and a better understanding of the role played by rodents awaits integration of historical and contemporary ecology. Today, the integration of these fields has become increasingly important, because invasions and threats of extinction continue, and because ecological restoration of islands frequently depends on understanding rodent ecology in order to predict the consequences of their removal (Towns and Broome 2003; Caut et al. 2007).

Based on the dramatic ecological impacts observed in contemporary field studies, ecologists have typically adopted a default hypothesis that invasive rats must have had strong impacts in the past (see critical review by Towns et al. 2006). In contrast, archaeologists and palaeoecologists have, until recently, viewed human-induced impacts on island ecosystems largely as consequences of forest clearing and fire. Focusing on such direct human activities, these researchers have been reluctant to attribute major impacts to the direct or indirect effects of rats. For us this contrast came into focus when Stephen Athens (Athens et al. 2002; see Athens 2008) reported findings from his integrated palaeoecological and archaeological research on the Ewa Plain of Oahu, Hawaiian Islands. Athens, an archaeologist, showed with a detailed palaeoenvironmental and archaeological record that rats ( $R$. exulans) introduced by Polynesians to the Hawaiian Islands some 1,000 years ago likely had a catastrophic impact on 
some native lowland forests. He offered this explanation for a record where fire or other direct human modifications of the forest (e.g. forest clearance for agriculture) could not account for widespread deforestation and the associated avifaunal extirpations. Athens's research in Hawaii stimulated wide discussion among ecologists, palaeoecologists, and archaeologists. Can invasive rats really play a significant role in island deforestation and species extinction? The answer seems to lie somewhere between historical and contemporary disciplines, calling upon researchers to integrate models from ecology with the diachronic trajectories of environmental change.

To begin to meet this challenge, we convened an interdisciplinary conference in 2007 at the University of Hawaii. Our goal was to examine the role of invasive rodents (especially Rattus spp.) on islands, from prehistoric to contemporary times. Our hope was to address the many questions that seemed to have fallen between ecological field studies and palaeoenvironmental research. The conference brought together more than 140 researchers from disparate fields, all of whom share an interest in building the foundations for an integrated understanding of rodents' roles in environmental transformations, for highlighting management issues, and fostering future research. The contents of this special issue of Biological Invasions represent the range of scientific fields and geographical regions examined by contributors to the conference.

\section{Palaeoecological and archeological evidence of rodent invasions}

The idea of islands as laboratories-comparative "experiments" in evolution-has long stimulated ecologists, biogeographers, human biogeographers, and archaeologists (e.g. MacArthur and Wilson 1967; Terrell 1997; Burney 1997; Fitzhugh and Hunt 1997; Drake et al. 2002; Vitousek 2002). Island ecosystems have been shaped by history, including effects of human colonization, biotic introductions, extinctions, and widespread direct and indirect habitat modifications. Research integrating archaeology and palaeoecology has provided records for dramatic and sometimes rapid biotic transformations of islands. At the same time, the historical ecological record has revealed that initial biotic invasions by humans (and their commensals) in pristine island ecosystems often have no clear analogs in contemporary environments. This makes the past all the more interesting from a biological perspective, but also more complicated given the uniqueness of these historical events and their profound and continuing effects.

Several papers in this special issue of Biological Invasions provide comparative and historical baselines detailing what we know of patterns of introduction of commensal vertebrates in the Pacific Islands (Anderson 2008; Matisoo-Smith and Robins 2008), as well as their prehistoric impacts (Athens 2008; Prebble and Wilmshurst 2008; Russell et al. 2008; see also Hunt 2007). The archaeological and palaeoecological records reveal how the effects of invasive species may vary significantly by island ecology, biogeography, and history. However, in many respects, detailed models for the ecology of invasive species and the relative vulnerability of islands remain to be more fully developed.

\section{Modern, direct impacts of invasive rodents}

Islands are renowned for having highly endemic and disharmonic biotas in which species often play unexpected ecological roles (Carlquist 1974; Drake et al. 2002; Whitaker and Fernandez-Palacios 2007). Because most remote islands lack native, terrestrial mammals, introduced rodents can assume highly novel ecological roles following colonization. Several contributions review the ecological effects of invasive rats (Rattus spp.) on specific groups of native taxa in specific island groups, including: rare plants in French Polynesia (Meyer and Butaud 2008), past and present invertebrates in New Zealand (Gibbs 2008), and land snails in Hawaii (Hadfield and Saufler 2008). In addition, Ruffino et al. (2008) use data from hundreds of Mediterranean islands to investigate how burrowing seabirds have managed to persist on some islands for 2,000 years after the introduction of $R$. rattus. They hypothesize that specific topographic features may provide refugia that minimize rats' access to burrows, thus allowing some birds to escape predation. Harris (2008) reviews the effects of introduced rodents (Rattus spp. and Mus musculus) on small, native, island mammals. It is 
surprising this topic has received so little attention, given the obvious theoretical interest in understanding, e.g. how introduced rodents interact with their nearest ecological equivalents-native rodents. Finally, Traveset et al. (2008) provide a comprehensive review of the impacts of seven species of invasive rodents on the native plants, invertebrates, reptiles, birds, and mammals of the Balearic and Canary Islands. In addition to direct impacts, some of these species of rodents are affecting plant populations and communities indirectly by altering pollination and seed dispersal mutualisms (see also Traveset and Richardson 2006). While research on the impacts of invasive rodents has revealed much, continuing studies point to many critical, yet largely unresolved issues in both ecological and palaeoecological timescales.

\section{Complex ecological interactions and their implications for management and restoration}

While the direct consumption of insular species by invasive rodents has been relatively well documented, far less is known about their community and ecosystem level effects (but see Fukami et al. 2006). Understanding these broader, often indirect ecological effects is a critical precursor to successful restoration of insular ecosystems following rodent eradication (Zavaleta et al. 2001; Lorvelec and Pascal 2005; Courchamp et al. 2003; Caut et al. 2007, 2008a). For example, Caut et al. (2008b) demonstrate how undesirable side effects of eradication (e.g. ecological release of other invasive alien species) can be predicted and circumvented by characterizing trophic interactions prior to the eradication. Mulder et al. (2008) compare sets of islands in New Zealand with different histories of invasion by-and eradication of $-R$. exulans. They conclude that some of the rats' main ecosystem-level effects occur because rats eliminate seabirds and hence seabird-associated nutrient inputs and physical disturbances. Thus, rat eradication alone is unlikely to return such islands to their original state; their restoration will require at least the reintroduction of seabirds. Towns (2008) uses patterns of island recovery following eradications of (mainly) $R$. exulans in New Zealand to estimate the original impacts of invasion. He notes that rodent eradications are not the reverse of rodent invasions, in part because natural recovery of island species is likely to be limited mainly to those not already eliminated from the islands by rats, or to those with good recolonizing ability. Ogden and Gilbert (2008) describe increases in populations of native plants and birds following suppression of three species of rodents on a large, inhabited island in New Zealand. They provide valuable insight into the social aspects of developing and carrying out alien species control when a large, resident community is directly involved.

\section{Other rodents}

Though they may be the most widely introduced rodents, it is clear from several of the above studies that rats are not the only invasive rodents that adversely affect islands. Simberloff (2008) systematically reviews the range of rodent species that have been introduced to islands (often deliberately) and points out their potential for ecosystem-level impacts. Finally, Angel et al. (2008) review the effects of the widely-distributed but underappreciated house mouse (Mus musculus) on islands in the Southern Ocean, where it is increasingly recognized as a conservation threat (Wanless et al. 2007), especially on islands lacking other introduced mammals.

\section{Future directions}

A valuable outcome of the conference, and papers resulting from it, has been to highlight areas in need of further research. A recurrent theme is the need for linkage across a range of ecological processes and timescales. For example, while there is ample evidence that invasive rats consume seeds of island plants (e.g. McConkey et al. 2003; Hunt 2007; Wilmshurst et al. 2008), direct field evidence for recruitment limitation is rare (Campbell and Atkinson 2002). Resolving this issue is complicated by ecosystem history, because some key ecological processes were undoubtedly altered before they could be studied directly (e.g. pollination, seed predation, or seed dispersal). Hence, we are often left with only contemporary patterns of plant abundance as evidence from which to infer the mechanism of population decline (e.g. Towns 2008). Controlled field and experimental research, crossreferenced with palaeoecological data, will be critical 
for determining which traits make plant species vulnerable or resistant to invasive rodents (e.g. seed size, chemical defenses, dependence on vulnerable mutualists, or evolution in the presence of endemic insular rodent species). Understanding these effects in more detail will enable us to disentangle direct impacts of rodents from those of other forces of environmental change, such as fire, forest clearance, or climate change. And, of course, the same arguments apply to understanding changes in island faunas. In addition, future research must address the complex, indirect effects of rodent invasions and eradications (Zavaleta et al. 2001; Fukami et al. 2006; Mulder et al. 2008). Indirect effects may best be studied by bringing ecologists and conservationists together to take advantage of planned eradications of rodents and reintroductions of native species, both of which should ideally be informed by paleoecological and historical data describing the target system's pre-rodent state.

In a broader sense, it is time to determine in what areas contemporary ecology, palaeoecology, and archaeology can inform each other and in what areas they cannot (Flessa and Jackson 2005). Because the same few species of rodents have invaded so many different islands, they may be ideal organisms for development of fine-grained models that integrate contemporary ecological studies with multiple lines of historical evidence from palaeoecology and archaeology.

\section{References}

Anderson A (2008) The rat and the octopus: initial human colonization and the prehistoric introduction of domestic animals to Remote Oceania. Biol Invasions. doi: 10.1007/s10530-008-9403-2

Angel A, Wanless RM, Cooper J (2008) Review of impacts of the introduced house mouse on islands in the Southern Ocean: are mice equivalent to rats? Biol Invasions. doi:10.1007/ s10530-008-9401-4

Athens JS (2008) Rattus exulans and the catastrophic disappearance of Hawaii's native lowland forest. Biol Invasions. doi:10.1007/s10530-008-9402-3

Athens JS, Tuggle HD, Ward JV, Welch DJ (2002) Avifaunal extinctions, vegetation change, and Polynesian impacts in prehistoric Hawai'i. Archaeol Ocean 37:57-78

Atkinson IAE (1985) The spread of commensal species of Rattus to oceanic islands and their effects on island avifaunas. In: Moors PJ (ed) Conservation of island birds. ICBP Technical Publication, Cambridge, pp 35-81
Burney DA (1997) Tropical islands as Paleoecological laboratories: gauging the consequences of Human arrival. Hum Ecol 25:437-457

Campbell DJ, Atkinson IAE (2002) Depression of tree recruitment by the Pacific rat (Rattus exulans Peale) on New Zealand's offshore islands. Biol Conserv 107:19-35

Carlquist S (1974) Island biology. Columbia University Press, New York

Caut S, Angulo E, Courchamp F (2008a) Dietary shift of an invasive predator: rats, seabirds and sea turtles. J Appl Ecol 45:428-437

Caut S, Angulo E, Courchamp F (2008b) Avoiding surprise effects on Surprise Island: alien species control in a multitrophic level perspective. Biol Invasions. doi:10.1007/ s10530-008-9397-9

Caut S, Casanovas JG, Virgos E, Lozano J, Witmer GW, Courchamp F (2007) Rats dying for mice: modelling the competitor release effect. Austral Ecol 32:858-868

Courchamp F, Chapuis J-L, Pascal M (2003) Mammal invaders on islands: impact, control and control impact. Biol Rev 78:347-383

Crosby AW (2004) Ecological imperialism: the biological expansion of Europe, 900-1900. Cambride University Press, Cambridge

Diamond J (1985) Rats as agents of extermination. Nature 318:602-603

Drake DR, Mulder CPH, Towns DR, Daugherty CH (2002) The biology of insularity: an introduction. J Biogeogr 29:563-569

Fitzhugh B, Hunt TL (1997) Introduction: islands as laboratories: archaeological research in comparative perspective. Hum Ecol 25:481-490

Flessa KW, Jackson ST (2005) Forging a common agenda for ecology and paleoecology. Bioscience 55:1030-1031

Fukami T, Wardle DA, Bellingham PJ, Mulder CPH, Towns DR, Yeates GW, Bonner KI, Durrett MS, Grant-Hoffman MN, Williamson WM (2006) Above- and below-ground impacts of introduced predators in seabird-dominated island ecosystems. Ecol Lett 9:1299-1307

Gibbs GW (2008) The end of an 80-million year experiment: a review of evidence describing the impact of introduced rodents on New Zealand's 'mammal-free' invertebrate fauna. Biol Invasions. doi:10.1007/s10530-008-9408-x

Grayson DK (2001) The archaeological record of human impacts on animal populations. J World Prehist 15:1-68

Hadfield MG, Saufler JE (2008) The demographics of destruction: isolated populations of arboreal snails and sustained predation by rats on the island of Moloka'i 1982-2006. Biol Invasions. doi:10.1007/s10530-008-9409-9

Harris DB (2008) Review of negative effects of introduced rodents on small mammals on islands. Biol Invasions. doi: 10.1007/s10530-008-9393-0

Hunt TL (2007) Rethinking Easter Island's ecological catastrophe. J Archeol Sci 34:485-502

Jones HP, Tershy BR, Zavaleta ES, Croll DA, Keitt BS, Finkelstein ME, Howald GR (2008) Severity of the effects of invasive rats on seabirds: a global review. Conserv Biol 22:16-26

Kennett D, Anderson A, Prebble M, Conte E, Southon J (2006) Prehistoric human impacts on Rapa, French Polynesia. Antiquity 80:340-354 
Kirch PV (1997) Microcosmic histories: island perspectives on 'global' change. Am Anthropol 99:30-42

Lorvelec O, Pascal M (2005) French attempts to eradicate nonindigenous mammals and their consequences for native biota. Biol Invasions 7:135-140

MacArthur RH, Wilson EO (1967) The theory of island biogeography. Princeton University Press, Princeton

Matisoo-Smith E, Robins J (2008) Mitochondrial DNA evidence for the spread of Pacific rats through Oceania. Biol Invasions. doi:10.1007/s10530-008-9404-1

McConkey KR, Drake DR (2002) Extinct pigeons and declining bat populations: are large seeds still being dispersed in the tropical Pacific? In: Levey DJ, Silva WR, Galetti M (eds) Seed dispersal and frugivory: ecology, evolution and conservation. CAB International, Wallingford, pp 381-395

McConkey KR, Drake DR, Meehan HJ, Parsons N (2003) Husking stations provide evidence of seed predation by introduced rodents in Tongan rain forests. Biol Conservation 109

Meyer J-Y, Butaud J-F (2008) The impacts of rats on the endangered native flora of French Polynesia (Pacific Islands): drivers of plant extinction or coup de grâce species? Biol Invasions. doi:10.1007/s10530-008-9407-y

Mulder CPH, Grant-Hoffman MN, Towns DR, Bellingham PJ, Wardle DA, Durrett MS, Fukami T, Bonner KI (2008) Direct and indirect effects of rats: does rat eradication restore ecosystem functioning of New Zealand seabird islands? Biol Invasions. doi:10.1007/s10530-008-9396-x

Ogden J, Gilbert J (2008) Prospects for the eradication of rats from a large inhabited island: community based ecosystem studies on Great Barrier Island, New Zealand. Biol Invasions. doi:10.1007/s10530-008-9398-8

Prebble M, Wilmshurst JM (2008) Detecting the initial impact of humans and introduced species on island environments in Remote Oceania using palaeoecology. Biol Invasions. doi:10.1007/s10530-008-9405-0

Ruffino L, Bourgeois K, Vidal E, Duhem C, Paracuellos M, Escribano F, Sposimo P, Baccetti N, Pascal M, Oro D (2008) Invasive rats and seabirds after 2,000 years of an unwanted coexistence on Mediterranean islands. Biol Invasions. doi:10.1007/s10530-008-9394-z

Russell JC, Abdelkrim J, Fewster RM (2008) Early colonisation population structure of a Norway rat island invasion. Biol Invasions. doi:10.1007/s10530-008-9406-z
Simberloff D (2008) Rats are not the only introduced rodents producing ecosystem impacts on islands. Biol Invasions. doi:10.1007/s10530-008-9400-5

Steadman DW (2006) Extinction \& biogeography of tropical pacific birds. University of Chicago Press, Chicago

Terrell JE (1997) The postponed agenda: archaeology and human biogeography in the twenty-first century. Hum Ecol 25:419-436

Towns DR (2008) Eradications as reverse invasions: lessons from Pacific rat (Rattus exulans) removals on New Zealand islands. Biol Invasions. doi:10.1007/s10530-0089399-7

Towns DR, Atkinson IAE, Daugherty CH (2006) Have the harmful effects of introduced rats on islands been exaggerated? Biol Invasions 8:863-891

Towns DR, Broome KG (2003) From small Maria to massive Campbell: forty years of rat eradications from New Zealand islands. N Z J Zool 30:377-398

Traveset A, Nogales M, Alcover JA, Delgado JD, Lopez-Darias M, Igual JM, Godoy D, Bover P (2008) A review of the effects of alien rodents in the Balearic (Western Mediterranean Sea) and Canary Islands (Eastern Atlantic Ocean). Biol Invasions. doi:10.1007/s10530-008-9395-y

Traveset A, Richardson DM (2006) Biological invasions as disruptors of plant reproductive mutualisms. Trends Ecol Evol 21:208-216

Vitousek PM (2002) Oceanic islands as model systems for ecological studies. J Biogeogr 29:573-582

Wanless RM, Angel A, Cuthbert RJ, Hilton GM, Ryan PG (2007) Can predation by invasive mice drive seabird extinctions? Biol Lett 3:241-244

Whitaker RJ, Fernandez-Palacios JM (2007) Island biogeography: eology, evolution and conservation. Oxford University Press, New York

Wilmshurst JM, Anderson AJ, Higham TFG, Worthy TH (2008) Dating late prehistoric dispersal of Polynesians to New Zealand using the commensal Pacific rat. Proc Natl Acad Sci USA 105:7676-7680

Wilmshurst JM, Higham TFG (2004) Using rat-gnawed seeds to independently date the arrival of Pacific rats and humans in New Zealand. The Holocene 14:801-806

Zavaleta ES, Hobbs RJ, Mooney HA (2001) Viewing invasive species removal in a whole-ecosystem context. Trends Ecol Evol 16:454-459 